\title{
OBITUARIES
}

\section{John Hilton Edwards}

\author{
Geneticist who recognised trisomy \\ 18 (Edwards' syndrome) and \\ the usefulness of chorionic villus \\ sampling
}

John Edwards, professor of genetics at Birmingham and Oxford, contributed to every aspect of his subject-in population, cytology, and trisomy studies, as well as radiation, blood group, and linkage studies. He developed a research tool, the Oxford grid, for mapping homologies between genetic sequences in different species. He recognised trisomy 18 in stillborn and abnormal babies-the condition named after him. He reported a series of 20 cases of Cornelia de Lange syndrome, a rare genetic disease. He also suggested that placental sampling, introduced to detect Rhesus negative babies, should also be used to detect chromosome abnormalities. His expertise in mathematics, statistics, and computer programming contributed to this.

Edwards was born in London, the son of a surgeon. He didn't learn to read until he was 9 , because he was rarely read to, which he later said gave him time to think. After qualifying in 1952 he did his national service in the Artists Rifles, part of the territorial SAS, where he learnt to parachute. He followed this with nine months as ship's doctor and make-do dentist on a scientific research ship, the John Biscoe, voyaging round the south Atlantic and Antarctic. On his return he was found to have pulmonary tuberculosis. He spent the ensuing bed rest teaching himself statistical methods.

After his recovery he spent three years in training posts in general medicine, neurology, pathology, and psychiatry. In 1956 he joined Birmingham University, where he was to spend 27 years. He started as lecturer in the social medicine department in the Institute of Child Health and rose to professor of human genetics, heading a new department of clinical genetics. During his first year there, placental sampling was introduced nationally and he suggested in a letter in the Lancet that it could be used for genetic screening.

He took leave from Birmingham to spend
1958-60 at the MRC population genetics unit in Oxford, returning to Birmingham regularly, where he recognised the defects caused by trisomy 18 . He spent a sabbatical (1960-1) at the Philadelphia Children's Hospital, and 1967-8 at the New York Blood Center and Cornell Medical College. During the latter period he attended the famous genetics course at Bar Harbor in Maine, organised and presented by Professor Victor McKusick of Baltimore, and in later years he taught on the course.

He was elected to fellowship of the Royal Society for "contributions to human cytogenetics and genetic epidemiology including elucidation of the threshold model for multifactorial traits and pedigree linkage analysis" in 1979.

He was then appointed to the chair of genetics in Oxford, where his main work was developing the Oxford grid, a chart for mapping and comparing homologous gene sequences in different species, a concept called syngeny. He collaborated with geneticists in Sydney, where there is an Oxgrid project.

He played a leading role in the international human gene mapping workshops held from 1973 to 1991 and directed the West Midlands Human Cytogenetics Laboratory for four years. He was a part time consultant in medical genetics at Oxford, visiting professor at the Memorial University of Newfoundland, genetics consultant to WHO from 1972, and a consultant investigator in Iceland, whose population is studied for its compact gene pool. His interests in restricted gene pools also extended to people in Labrador and Newfoundland, pigs in Australia, and sheep in New Zealand. He co-edited Genetic Mapping of Human Genes (1997) and published over 100 papers.

At the Birmingham social medicine department his mentor was Lancelot Hogben, author of Mathematics for the Million, one of the most successful popular maths books of all time. John Edwards's mathematician brother Anthony had a parallel career as genetics professor at Cambridge, originally working under the statistician R A Fisher. The two brothers were nicknamed Hogben's Edwards and Fisher's Edwards.

John Edwards's absent mindedness was legendary. He twice arrived at Heathrow without his passport. He travelled from Oxford to the Athenaeum without realising

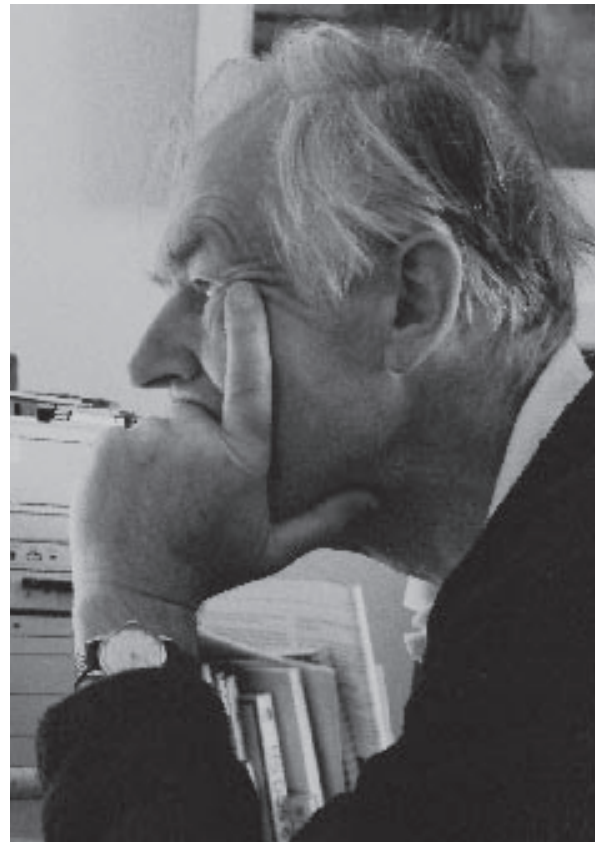

that his dress trousers were 5 inches too short, his daughter having tacked them up for a fancy dress party. He once oiled his skis with a tube of processed cheese. He sometimes bought several copies of the same book. In New York he posted his Christmas cards in a litter bin attached to a lamp post. When looking after his first child for the first time, he mislaid her. She was on his lap, under an open volume of Encyclopaedia Britannica.

He frequented book fairs and read widely, with a particular fondness for Martin Gardner, Edward Gibbon, and G K Chesterton. $\mathrm{He}$ had a recreational interest in mathematics, and did his own computer programming from the outset. When his children were young he took them to the cinema and worked out mathematical formulas on the backs of punchcards in the near darkness. In his retirement he took an interest in leprosy and collaborated with the head of the Indian medical research council.

He was diagnosed with prostate cancer in 2000 but remained active until a relapse in July 2006. He leaves a wife, Felicity, and four children.

John Hilton Edwards, emeritus professor of clinical genetics Oxford University (b 1928; q Cambridge/Middlesex Hospital 1952; FRS, FRCP), d 11 October 2007.

Caroline Richmond 